\title{
Progesterone Receptor Gene Polymorphism Promoter Region +331G/A Increases Risk of Endometriosis
}

\author{
Polimorfisme Gen Reseptor Progesteron Regio Promoter +331 G/A \\ Meningkatkan Risiko Terjadinya Endometriosis
}

\author{
Syifa Alkaf', Aerul Chakra1, Usman Said', Irsan Saleh² \\ ${ }^{1}$ Department of Obstetrics and Gynecology \\ ${ }^{2}$ Health and Medicine Research Unit \\ Faculty of Medicine University of Sriwijaya/ \\ Dr. Mohammad Hoesin General Hospital \\ Palembang
}

\begin{abstract}
Objective: To identify relationship between progesterone receptor gene polymorphism promoter region $+331 \mathrm{G} / \mathrm{A}$ with the risk of endometriosis.

Method: An observational case-control study. Population are women with endometriosis and/or adenomyosis who have been performed laparotomy/laparoscopy at Obstetrics and Gynecology Department Dr. Mohammad Hoesin General Hospital Palembang, January-November 2013. Subjects fulfilled inclusion criteria, given informed consent and performed blood sampling continued by PCRRFLP. Results were divided into A/A genotype (homozygote mutant), G/A (heterozygote mutant), and G/G (homozygote wild type) Data were analyzed by SPSS 21.0 version.

Result: PCR-RFLP results for+331G/A genotype were 26 (54.1\%) in case group and $14(26.4 \%)$ in control. $+331 \mathrm{~A} / \mathrm{A}$ genotype was no found in both groups. There was significant increase risk of endometriosis in women carrying genotype +331G/A to those with genotype $+331 \mathrm{G} / \mathrm{G}$ with OR $3.29(\mathrm{p}<0.05)$

Conclusion: Polymorphism on progesterone receptor gene $+331 \mathrm{G} / \mathrm{A}$ increases risk of endometriosis in Malay population in Indonesia. Compared to previous studies, there is interesting finding that polymorphic alels were found more commonly in our study.

[Indones J Obstet Gynecol 2016; 1: 52-56]
\end{abstract}

Keywords: endometriosis, polimorphism, progesterone reseptor, $+331 \mathrm{G} / \mathrm{A}$

\begin{abstract}
Abstrak
Tujuan: Mengetahui hubungan polimorfisme gen reseptor progesteron regio promoter $+331 G / A$ dengan risiko terjadinya endometriosis.

Metode: Sebuah studi kasus kontrol observasional dengan populasi perempuan penderita endometriosis dan/atau adenomiosis yang dioperasi laparotomi/laparoskopi di Bagian Obstetrik dan Ginekologi RSUP Dr. Mohammad Hoesin Palembang dari Januari sampai November 2013. Subjek yang memenuhi kriteria inklusi, dilberikan informed consent selanjutnya dilakukan pengambilan darah dilanjutkan pemeriksaan PCR-RFLP. Hasil pemeriksaan dibagi menjadi genotif A/A (mutan heterozigot), G/A (mutan homozigot), dan $G / G$ (wild type). Analisis data menggunakan program SPSS versi 21.0

Hasil: I PCR-RFLP didapat genotif +331 G/A sebanyak $26(54,1 \%)$ pada kasus dan 14 (26,4\%) pada kontrol. Pada kedua kelompok genotif $+331 A /$ A tidak ditemukan. Terdapat peningkatan risiko endometriosis pada perempuan dengan genotif $+331 G / A$ dibanding $+331 G / G$ dengan rasio odd 3,29 $(p<0,05)$.

Kesimpulan: Polimorfisme pada gen reseptor progesteron $+331 \mathrm{G} / \mathrm{A}$ meningkatkan risiko endometriosis pada populasi ras Melayu $d i$ Indonesia. Dibandingkan penelitian terdahulu, menarik mengetahui alel polimorfik ditemukan dalam jumlah yang banyak pada studi ini. [Maj Obstet Ginekol Indones 2016; 1: 52-56]
\end{abstract}

Kata kunci: endometriosis, polimorfisme, reseptor progesteron, $+331 G / A$

Correspondence: Syifa Alkaf. Obstetrics and Gynecology Department. Faculty of Medicine University of Sriwijaya Palembang. Telephone : +62711-360865, Email:dear.syifa@gmail.com

\section{INTRODUCTION}

Endometriosis is a benign gynecologic condition characterized by presence of endometriotic tissue outside the uterine cavity. Chronic pelvic pain and infertility are two of its most common symptoms. Endometriosis is commonly found and affects about 5-10 \% reproductive age women and more than $30 \%$ infertile women. ${ }^{1-4}$

Genetics study in endometriosis is attracting researchers in recent years. One of interest is poly- morphism in progesterone receptor gene. Progesterone is a potent antagonist of estrogen-mediatedproliferation in endometrium and plays an important role in pathogenesis of endometriosis. Progesterone regulates this crusial function by its two isoform, A and B, which are expressed by one single gene located in chromosome 11q22-q23. PR$A$ is commonly found in endometrial stroma while PR-B in glandular which function by inducing cell apoptosis and secretoric change, repectively. PR-B acts as strong transcription activator to proges- 
terone target genes, while PR-A is a dominat transrepressor of PR-B and ER- $\alpha$ activity antiproliferative effect of progesterone depends on balance of these two isoforms. ${ }^{3,5-8}$

McDonnel, et al. ${ }^{9}$ found the mechanism of which PR-A inhibits PR-B transcription activity by competitive inhibition to general transcription factor of mineralocorticoid receptor. While in non transcriptionally active cells, PR-A functions as glucocorticoid inhibitors, PR-B, and androgen receptor. Thus, repression of transcription activity of estrogen receptor depends on PR-A expression. ${ }^{10-12}$

Functional polymorphism at promoter region $+331 \mathrm{G} / \mathrm{A}$ of receptor progesterone gene (rs108 95068), by adding TATA box the transcription start site, promotes production PR-B relative to PR-A. Change in PR-A/PR-B ratio is believed to interfere stromal differentiation and lead to progesterone resistance. Thus, our hypothesis is that DNA polymorphism in progesterone receptor gene which interferes PR-A/PR-B ratio increases risk of endometriosis. ${ }^{13}$

\section{METHODS}

This was a case control study took place in Obstetrics and Gynecology Department and Microbiology Laboratory Dr. Mohammad Hoesin Hospital Palembang from Januari to November 2013.

Population were women with endometriosis and/or adenomyosis who have been performed laparotomy or laparoscopy in Obstetrics and Gynecology Department Dr. Mohammad Hoesin General Hospital Palembang.

Inclusion criteria were those in age 13-45 years and still have period. Endometriosis women who were pregnant, having ovarian carcinoma and myoma were excluded from the study. Controls were patients who undergone laparotomy or laparoscopy for other reasons and proven not having endometriosis and/or adenomyosis.

Blood samples were collected in EDTA tube and refrigerated in maximum temperature of $4^{\circ} \mathrm{C}$ until DNA extraction performed. Extraction was conducted using Chelex-100 method with phosphate buffer saline (PBS) pH 7.4; Safonin 0.5\% in PBS; and Chelex $20 \%$ in $\mathrm{ddH}_{2} \mathrm{O}$ pH 10.5 .

DNA genome fragments were multiplied in vitro using oligonucleotide amplification primer pair to limit ampification area. We used 18pmol primer
Forward 5'-CACTCATGGGATCTGAGAATC-3' and 18pmol reverse primer 5'-CACAAGTCCGGCACTT GAGT-3'. PCR was performed using lab cycler (Sensquest).

Polymorphism G/A in progesterone receptor promoter region +331 was detected from RFLP (restriction fragment length polymorphism) using retriction enzyme NlaIV.

PCR products with $330 \mathrm{bp}$ length were digested by 1.0 unit NlaIV (isoschizomerBspLI, fermentas) with buffer reaction and incubated in $37^{\circ} \mathrm{C}$ temperature for 180 minutes. Then $5 \mu$ l compound was poured into $2 \%$ polyacrylamide gel electrophoresis (PAGE) containing ethidium-bromide, then continued with electophoresis and visualized under ultra violet using Gel-Dov (BIO-RAD laboratories USA). Results were then analyzed using Quantity One software.

\section{RESULTS}

Within periods of January to November 2013, there were 101 subjects, 48 in case group and 53 in control group.

Mean age in case group of this study was 35.8 years. It corresponded with data showed that average age for endometriosis patients were 35-45 years. Patients in case group have significantly lower BMI than in control. More than half patients with endometriosis experienced infertility (52.1\%), while only $7.5 \%$ of control group having infertility, $\mathrm{p}<0.001$.

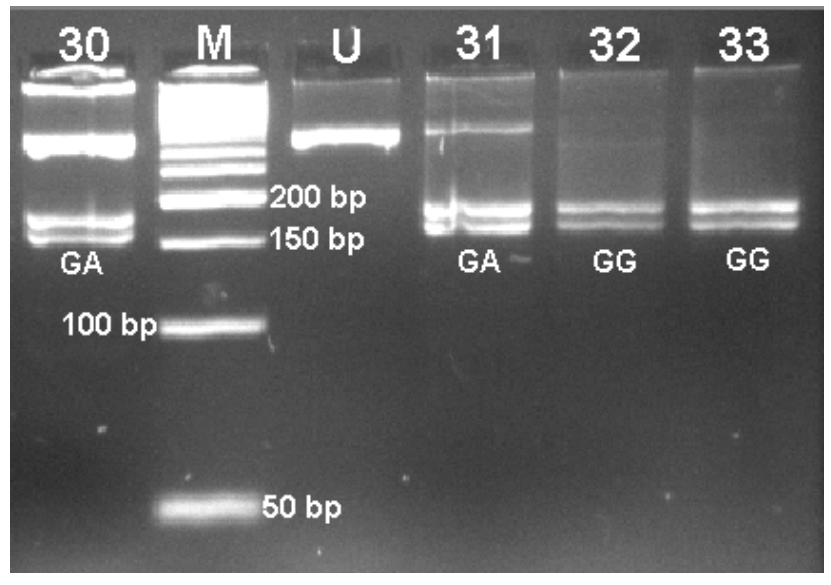

Figure 1. Visualization Result after pcr-RFLP 
Table 1. Subject Sosiodemographic Characteristic

\begin{tabular}{|c|c|c|c|c|c|}
\hline \multirow{2}{*}{ Characteristic } & \multicolumn{2}{|c|}{ Case } & \multicolumn{2}{|c|}{ Control } & \multirow{2}{*}{$\mathbf{p}$} \\
\hline & $\Delta$ & $\%$ & $\Delta$ & $\%$ & \\
\hline Mean age (year) & 35,8 & & 28,11 & & $<0.001$ \\
\hline \multicolumn{6}{|l|}{ Parity } \\
\hline Nulliparous & 33 & 68.8 & 24 & 9.4 & \multirow{3}{*}{$<0.001$} \\
\hline Primigravid & 7 & 14.6 & 24 & 45.3 & \\
\hline Multigravid & 8 & 16.7 & 24 & 45.3 & \\
\hline Mean BMI & 22.96 & & 25.47 & & 0.003 \\
\hline \multicolumn{6}{|l|}{ Etnic group } \\
\hline South Sumatra & 37 & 77.1 & 39 & 73.6 & \multirow{5}{*}{0.358} \\
\hline Jawa & 8 & 16.7 & 10 & 18.9 & \\
\hline Minang & 1 & 2.1 & 2 & 3.8 & \\
\hline Cina & 2 & 4.2 & 0 & 0 & \\
\hline Others & 0 & 0 & 2 & 3.8 & \\
\hline \multicolumn{6}{|l|}{ Marital status } \\
\hline Married & 44 & 91.7 & 50 & 94.3 & \multirow{2}{*}{0.597} \\
\hline Unmarried & 4 & 8.3 & 3 & 5.7 & \\
\hline \multicolumn{6}{|l|}{ Abortus history } \\
\hline$(+)$ & 3 & 6.3 & 9 & 17.0 & \multirow{2}{*}{0.128} \\
\hline$(-)$ & 45 & 93.8 & 44 & 83.0 & \\
\hline \multicolumn{6}{|l|}{$\begin{array}{l}\text { Hormonal } \\
\text { contraception }\end{array}$} \\
\hline$(-)$ & 36 & 75.0 & 41 & 77.4 & \multirow{2}{*}{0.255} \\
\hline$(+)$ & 12 & 25.0 & 12 & 22.6 & \\
\hline \multicolumn{6}{|l|}{ Infertility } \\
\hline$(+)$ & 25 & 52.1 & 4 & 7.5 & \multirow{2}{*}{$<0.001$} \\
\hline$(-)$ & 23 & 47.9 & 49 & 92.5 & \\
\hline \multicolumn{6}{|l|}{ Smoking } \\
\hline$(+)$ & 1 & 2.1 & 2 & 3.8 & \multirow{2}{*}{1.00} \\
\hline$(-)$ & 47 & 97.9 & 51 & 96.2 & \\
\hline \multicolumn{6}{|l|}{ Family history } \\
\hline$(+)$ & 3 & 6.3 & 5 & 9.4 & \multirow{2}{*}{0.718} \\
\hline$(-)$ & 45 & 93.8 & 48 & 90.6 & \\
\hline
\end{tabular}

Table 2. Distribution and Analysis of Progesterone Receptor Genotype

\begin{tabular}{lccc}
\hline \hline \multicolumn{1}{c}{ Genotype } & Case & Control & Total \\
\hline $\begin{array}{l}\text { Genotype } \\
+331 \mathrm{G} / \mathrm{A}\end{array}$ & $26(54.1 \%)$ & $14(26.4 \%)$ & 40 \\
$\begin{array}{l}\text { Genotype } \\
+331 \mathrm{G} / \mathrm{G}\end{array}$ & $22(45.8 \%)$ & $39(73.5 \%)$ & 61 \\
& & & $\begin{array}{c}\text { OR: } 3.292 \\
(95 \% \mathrm{CI} 1.43-\end{array}$ \\
Total & 48 & 53 & \begin{tabular}{l}
$7.58), \mathrm{p}<0,01$ \\
\hline
\end{tabular} \\
\hline \hline
\end{tabular}

It can be said from the Table 2. that distribution of mutant heterozygote genotype was found more commonly in case group than control, $\mathrm{p}<0,01$. There was increase risk of endometriosis in women carrying progesterone receptor gene promoter region $+331 \mathrm{G} / \mathrm{A}$, with odd ratio 3.29 (95\% CI.43-7.58). Homozigote mutant genotype $(+331 \mathrm{~A} / \mathrm{A})$ was not found in either group. Maybe because limitation of number of subjects studied.

We then further analyzed relationship between these two genotypes found in case groups with other variables such endometriosis level, infertility, and dysmenorhae. Correlation value between genotype $+331 \mathrm{G} / \mathrm{A}$ and endometriosis level based on ASRM was weak (0.27) with $\mathrm{p}>0.05$ (Table 3). Genotype +331G/A had also weak correlation with dysmenorhae level, $\mathrm{r} 0.32$ with $\mathrm{p}>0.05 .^{14}$

Table 3. Distribution and Correlation Test between Genotypes and ASRM Endometriosis Level, and Genotypes with Dysmenorrhea Level in Case Group

\begin{tabular}{|c|c|c|c|c|c|c|c|c|c|c|}
\hline \multirow[t]{2}{*}{ Genotype } & \multicolumn{5}{|c|}{ Endometriosis level } & \multicolumn{5}{|c|}{ Dysmenorrhae level } \\
\hline & I & II & III & IV & Total & No pain & Mild & Moderate & Severe & Total \\
\hline +331 G/A & $\begin{array}{c}1 \\
4.5 \%\end{array}$ & $\begin{array}{c}6 \\
27.3 \%\end{array}$ & $\begin{array}{c}6 \\
27.3 \%\end{array}$ & $\begin{array}{c}9 \\
40.9 \%\end{array}$ & 22 & $\begin{array}{c}4 \\
15.3 \%\end{array}$ & $\begin{array}{c}6 \\
23.0 \%\end{array}$ & $\begin{array}{c}8 \\
30.7 \%\end{array}$ & $\begin{array}{c}8 \\
30.7 \%\end{array}$ & 26 \\
\hline$+331 \mathrm{G} / \mathrm{G}$ & $\begin{array}{c}0 \\
0.0 \%\end{array}$ & $\begin{array}{c}4 \\
19.0 \%\end{array}$ & $\begin{array}{c}3 \\
14.3 \%\end{array}$ & $\begin{array}{c}14 \\
66.7 \%\end{array}$ & 21 & $\begin{array}{c}1 \\
4.5 \%\end{array}$ & $\begin{array}{c}1 \\
4.5 \%\end{array}$ & $\begin{array}{c}10 \\
45.5 \%\end{array}$ & $\begin{array}{c}10 \\
45.5 \%\end{array}$ & 22 \\
\hline $\begin{array}{l}\text { Total* } \\
\text { (\%) }\end{array}$ & 1 & 10 & 9 & 23 & $\begin{array}{c}43 \\
\mathrm{p}=0.33 \\
\mathrm{r}=0.27\end{array}$ & 5 & 2 & 23 & 18 & $\begin{array}{c}48 \\
\mathrm{p}=0.14 \\
\mathrm{r}=0.32\end{array}$ \\
\hline
\end{tabular}




\section{DISCUSSION}

There was significant age difference between case and control group. This can be explained because most subjects in control group were primiparous where as the others were mostly women who seeking for help after years of infertility. More than half of case group were infertile. This finding was along with the fact that endometriosis is one of commonest cause of infertility. ${ }^{15}$

Some previous researchers reported of specific group of women with tall and thin posture, short ovulatoar cycle, and heavy menstrual bleeding as to be "endometriosis phenotype". Women with normal BMI tend to have more regular cycle than those with higher BMI. From our findings, BMI average in case group was significantly lower than those in control group.

We also find in this study that presence of $+331 \mathrm{G} / \mathrm{A}$ genotype increased the risk of endometriosis with OR 3.29. While correlation of this genotype with the ASRM level and dysmenorrhea score was weak. Limitation of sample size and consecutive sampling methods were rationale of this result. ${ }^{16}$

Gentilini et al. ${ }^{17}$ showed that this $+331 \mathrm{G} / \mathrm{A}$ polymorphic gene increased risk for deep infiltrating endometriosis with high invasive potential. It was assumed that PR-B, with a nontranscriptional mechanism, provokes cell development through interaction with estrogen receptor and stimulates $\mathrm{Src} / \mathrm{P} 21 \mathrm{ras} /$ ERK pathway. In investigating progesterone receptor on uterine myoma, Renner, et al. ${ }^{14}$ found that $+331 \mathrm{G} /$ A genotype was related to endometriosis incidence in myoma patients, which means this genotype was found more common in myoma patients having endometriosis.

De Vivo, et al. ${ }^{18}$ stated that progesterone receptor gene polymorphism enhanced risk for endometrial cancer by increasing PR-B receptor expresssion.

This polymorphism was not related to cell ability to implant on ectopic sites but rather enabling cell invasiveness by altering PR-A and PR-B balance.

Different from those findings, Kaam, et al. ${ }^{13}$ detected that $+331 \mathrm{~A}$ allele reduced risk of deep infiltrating endometriosis and adenomyosis. From our concideration, this result might be bias since allele $+331 \mathrm{~A}$ only found in 2 subjects. It was also re- ported from this study that ovarian ca patients did not show increase on $+331 \mathrm{~A}$ allele significantly.

Berchuck, et al. ${ }^{11}$ reported lessen endometriosis risk on $+331 \mathrm{~A}$ variant allele in women participating in the study of ovarian carcinoma. Treloar, et al. ${ }^{19}$ found there was no relationship between endometriosis risk with this variant.

Difference on study results were probably from different sample size, population and demography thus evoked variations in polymorphism pattern reported. In this study, conducted in Indonesia, we assumed to represented Malay population in Indonesia. On our best knowledge, this study was the first taken place in Indonesia. Previous researchers in different countries and etnic group reported various results. As we know, single nucleotide polymorphism is an inherited form and the incidence will be different among races. ${ }^{20-24}$

From this study we can conclude an interesting fact that polymorphism frequency in progesterone receptor gene promoter region $+331 \mathrm{G} / \mathrm{A}$ were found frequently in subjects, $54.1 \%$ in case group and $26.4 \%$ in control. Remembering that polymorphism is variable among groups and places, this study took place in Sumatera Selatan Indonesia revealed an attracting result.

Limitation of this study is that we did not analyzed progesterone receptor gene expression in endometriotic tissues. This gene expression examination is crucial to see how significant genotype polymorphism on tissue level, and to evaluate factors contributing to this.

\section{CONCLUSION}

Polymorphism on progesterone receptor gene promoter region $+331 \mathrm{G} / \mathrm{A}$ has significant relation with endometriosis. There is significant increase risk of endometriosis on Malay population in Indonesia having +331G/A gene compared to $+331 \mathrm{G} / \mathrm{G}$ gene . While endometriosis level based on ASRM as well as dysmenorrhea level are on weak correlation with this gene polymorphism.

\section{REFERENCES}

1. Cramer DW, Missmer SA. Cramer \& Missmer: Epidemiology of endometriosis. Annals New York Academy of Sciences. Harvard Medical School. Boston. 2011: 11-22.

2. Vigano P, Prazzini F, Somigliana E, Vercellini P. Endometriosis: epidemiology and aetiological factors. Best Prac Research Clin Obstet Gynecol. 2004; 18(2): 177-200. 
3. Bedaiwy MA, Falcone T. Laboratory testing for endometriosis. Clin Chimica Acta. 2004; 340: 41-56.

4. Matarese G, Placido GD, Nikas Y, Alviggi C. Pathogenesis of endometriosis: natural immunity dysfunction or autoimmune disease? Trends Mol Med. 2003; 9(5): 223-8.

5. Augoulea A, Alexandrou A, Creatsa M, et al,. Pathogenesis of endometriosis: the role of genetics, inflammation, and oxidative stress. Arch Gynecol Obstet. 2012; 286: 99-103.

6. Attia GR, Zeitoun K, Edwards D, et al,. Progesterone receptor isoform A but not B is expressed in endometriosis. J Clin Endocrin Metabol. 2000; 85(6): 2897-902.

7. Merck MF, Misrahi M, Loosfelt $\mathrm{H}$, et al,. Localization of the human progesterone receptor gene to chromosome 11q22q23. Hum Genet. 1987(77): 280-2.

8. Yang S, Thiel KW, Leslie KK. Progesteron: the ultimate endometrial tumor supressor. Trends Endocrinol Metab. 2011; 22(4): 145-52.

9. Mc Donnel DP, Shahbaz MM, Vegetto E, et al,. The human progesteron receptor A-form functions as transcriptional modulator of mineralocorticoid receptor transcriptional activity. J Steroid Biochem Mol Biol. 1994; 48(5/6): 425-32.

10. Fritz MA, Speroff L. Clinical gynecologic endocrinology and infertility. $8^{\text {th }}$ edition. Philadelpia: Lippincot Williams \& Wilkins; 2011.

11. Berchuck A, Schildkraut JM, Wenham R, et al. Progesterone receptor promoter $+331 \mathrm{~A}$ polymorphism is associated with reduced risk of endometrioid and clear cell ovarian cancers. Cancer Epidemiol Biomarkers Prev. 2004; 13: 2141-7.

12. Wen DX, Xu YW, Mais DE, et al,. The A and B isoform of the human progesterone receptor operate through distinct signalling pathways within target cells. J Mol Cel Biol. 1994; 14(12): 8356-64.

13. Kaam KV, Romano A, Schouten JP, et al,. Progesterone receptor polymorphism $+331 \mathrm{G} / \mathrm{A}$ is associated with a decreased risk of deep infiltrating endometriosis. Hum Reprod. 2006; 22: 129-35.

14. Renner SP, Strick R, Fasching PA, et al,. Single nucleotide polymorphism in the progesterone receptor gene and association with uterine leiomyoma tumor characteristics and disease risk. Am J Obstet Gynecol. 2008; 684: 1-9.
15. Foda AA, Abdel IA. Role of some biomarkers in chronic pelvic pain for early detection of endometriosis in infertile women. Middle East Fertil Society J. 2012.

16. Hestiantoro A, Natadisastra M, Sumapraja K, et al,. editor. Best practice on IMPERIAL. Ed pertama. Jakarta: Sagung Seto; 2012.

17. Gentilini D, Vigano P, Carmignani L, et al,. Progesterone receptor $+331 \mathrm{G} /$ A polymorphism in endometriosis and deep infiltrating endometriosis. Fertil Steril. 2008; 90(4): 1243-5.

18. De Vivo I, Huggins GS, Hankinson SE, et al,. A functional polymorphism in the promoter of progesterone gene is associated with endometrial cancer risk. PNAS. 2002; 99(19): 12263-8.

19. Treloar SA, Zhao ZZ, Armitage TA, et al,. Association between polymorphisms in progesterone receptor gene and endometriosis. Mol Hum Reprod. 2005; 11(9): 641-7.

20. Smith K. Genetic polymorphism and SNPs; genotyping, haplotype assembly problem, haplotype map, functional genomics and proteomics. 2002.

21. Abdullah N. Analisis polimorfisme gen vascular endothelial growth factor (VEGF) pada endometriosis. Maj Obstet Ginekol Indones. 2009; 33-2: 108-17.

22. Hutajulu P. Ekspresi pinoda pasien endometriosis kajian polimorfisme gene alpha $\mathrm{V}$ integrin, beta 3 integrin, homeobox A-10, dan ekspresi gena alpha $\mathrm{V}$ beta 3 integrin dan homeobox A-10. Electronic Theses \& Dissertation Gajah Mada University. 2013.

23. Soeharso P. Polimorfisme dan isoform gen reseptor FSH perempuan Indonesia: implikasinya pada penanganan infertilitas dan kesehatan reproduksi. Universitas Indonesia. 2004.

24. Hestiantoro A, Dewi ANP, Hadisaputra W, et al,. Hubungan polimorfisme gen adiponectin + SNP276 G>T dengan risiko endometriosis. Perfitri Update. Ed 1. 2009. 